https://doi.org/10.4314/ijs.v22i1.1

Ife Journal of Science vol. 22, no. 1 (2020)

\title{
REPRODUCTIVE BIOLOGY OF FOUR WEEDY EUPHORBIA SPECIES FROM ILE-IFE, NIGERIA
}

\author{
*Bolaji A. O., Idowu-Aiye M. and Moronfade H. O. \\ Botany Department, Obafemi Awolowo University Ile-Ife, Nigeria \\ *Corresponding author's e-mail: abolaji@oauife.edu.ng \\ (Received: 30 ${ }^{\text {th }}$ October, 2019; Accepted: $19^{\text {th }}$ January, 2020)
}

\section{ABSTRACT}

\begin{abstract}
Euphorbia heterophylla Linn., Euphorbia hirta Linn., Euphorbia hyssopifolia Linn. and Euphorbia prostrata Linn. are four noxious, yet economically important weeds, useful as phytomedicine in some parts of the world and also in Nigeria. Studies were carried out on their reproductive biology with a view to understanding the mode of their spread. Parameters investigated include number of days to seedling emergence, germination percentage, number of days to flowering, period to anthesis, pollinators, pollen viability, pollen size, floral structure, fruits type, seeds type, average number of fruit per plant, average number of seeds per plant and mode of seed dispersal. Results obtained showed that the seedlings of the four Euphorbia species studied emerged within 3 to 5 days; numbers of days to $50 \%$ flowering took 44 to 58 days; while flowering and fruiting continued throughout the remaining part of the year; thus exhibited r-strategy, expending more time and allocation of resources on their reproductive phases than their vegetative phases. Also differences existed in their stigma shape, perianth colour, perianth texture, pollen sizes, pollen viability as well as ripened colour of seed which were all significant characters that could be useful in delimiting the species. Furthermore, the study revealed that the four species were essentially insect pollinated and their seeds dispersed by means of explosive mechanism usually characteristic of their schizocarpic fruits. This ability as well as their tendency to exhibit r-strategy could probably account for their ability to spread and invade cultivated fields, waste lands and roadsides.
\end{abstract}

Keywords: Explosive mechanism, r-Strategy, Seed dispersal, Pollen viability, Seed set

\section{INTRODUCTION}

The genus Euphorbia consists of about 2000 species and it is the most diverse group of flowering plants on earth (Prenner and Rudall, 2007). There are about 30 species in West Africa out of which about 21 species are well represented in Nigeria (Hutchinson and Dalziel, 1954). Many members of the Euphorbia genus belong to a primary system of chromosome number with basic chromosome number of $\mathrm{n}=8$ and a secondary chromosome number of $n=6,7,9$ and 10 resulting from aneuploidy and polyploidy (Huang et al., 2012, Bolaji et al., 2015).

Euphorbia heterophylla Linn., Euphorbia hirta Linn., Euphorbia byssopifolia Linn. and Euphorbia prostrata Linn. upon which the investigations in this study are based are not only noxious invasive herbaceous weedy Euphorbia species that grow on cultivated lands, road sides and waste lands but are also plants of medicinal importance used for treatment of various ailments in many parts of the world, including Nigeria (Herbenger, 1997; Johnson et al., 1999; Falodun and Agbakwuru, 2004; Tabuti, 2008; Sandeep et al., 2009; Bolaji et al., 2019).

Although there have been reports on various aspects of the morphology, cytology and phylogenetic relationship of some of the members of the genus Euphorbia, there is paucity of information on many aspects of their reproductive biology. This investigation becomes necessary because it is an important step to understanding the mode of their spread. This study therefore seeks to address this knowledge gap by reporting many aspects of the reproductive biology of $E$. beterophylla, E. hirta, E. byssopifolia and $E$. prostrata that have not been previously reported with a view to providing insightful information that could become very useful in the control of their spread.

\section{MATERIALS AND METHODS}

Whole plant collections of Euphorbia beterophylla, E. hyssopifolia and E. prostrata from the wild as well as cultivated forms raised from their seeds were investigated in this study. The 
Euphorbia species were obtained from various

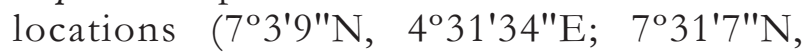
431'28"E; 7०31'8"N, 4³1'35"E) within Ile-Ife, Nigeria. These were identified at the IFE Herbarium, Department of Botany, Obafemi Awolowo University, Ile-Ife, Nigeria.

Apart from the characterization of the floral attributes of the four Euphorbia species being investigated in this study, other parameters pertaining to their reproductive biology which were documented include: number of days to seedling emergence, germination percentage, number of days to $50 \%$ flowering, period to anthesis, percentage pollen viability, average number of fruits per plant, average number of seeds per plant, types of pollinators, colour of ripe and unripe fruit, colour and types of seeds as well as mode of seed dispersal.

The germination study was carried out on $8 \mathrm{~cm}$ petri dishes laid with $7 \mathrm{~cm}$ Whatman filter paper. Thirty (30) seeds were sown in each petri dish in four replicates. Days to emergence of radicle were documented and the percentage of seeds that germinated was also determined using the formula:

Percentage germination $=$

Number of seeds that germinated $\times 100$

Total number of seeds sown

The details of the structure of the cyanthia of the four different species studied were investigated with the aid of the dissecting microscope; while the pollen viability study was carried out by harvesting pollen grains from freshly-dehisced anthers onto microscope slides. They were stained with Cotton-Blue-in-Lactophenol for 30 minutes and examined under the light microscope for percentage stainability following the methods of Bolaji and Nwokeocha (2013). The well-formed and deeply stained pollens were considered viable while those with collapsed outline and partially stained or not stained at all were considered to be non-fertile (Faluyi, 1985). One hundred (100) pollens were scored at $\times 40$ magnification for percentage stainability. The pollen size was also measured using ocular micrometer.

\section{RESULTS}

The photograph of a typical Euphorbia beteropbylla studied is shown in figure 1A. The seedlings emerged 5 days after sowing and had $11.6 \%$ germination. The number of days to $50 \%$ flowering was 48 days and it continued to bloom throughout the year. The inflorescence was cyathium (cyme); flowers bisexual with green pedicel, glabrous perianth, white in colour; ovary superior, green in colour, glabrous, 3-lobed; placentation axile, style single, hollow, green in colour; stigma reddish brown, branched into four; stamen hypogynous, epipetalous; filament green, anther sticky, brown, numerous and attached to the wall of the perianth; fruit schizocarpous, 3lobed, unripe fruit colour light green, ripe fruit colour green; seed carunculate, unripe seed colour white, ripe seed colour brown (Figure 2). Pollinators that visited the inflorescence were Calliphora vomitora (blue-fly) and the mode of seed dispersal was by explosive mechanism. The anthesis took place between $9 \mathrm{am}-11 \mathrm{am}$ in the morning. It had an average pollen size of $3.5 \pm$ $0.04 \mu \mathrm{m}, 83.49 \%$ pollen viability; while the mean number of fruit and seed per stand were $28 \pm$ 26.74 and $70 \pm 16.88$ respectively (Table 1 ). 

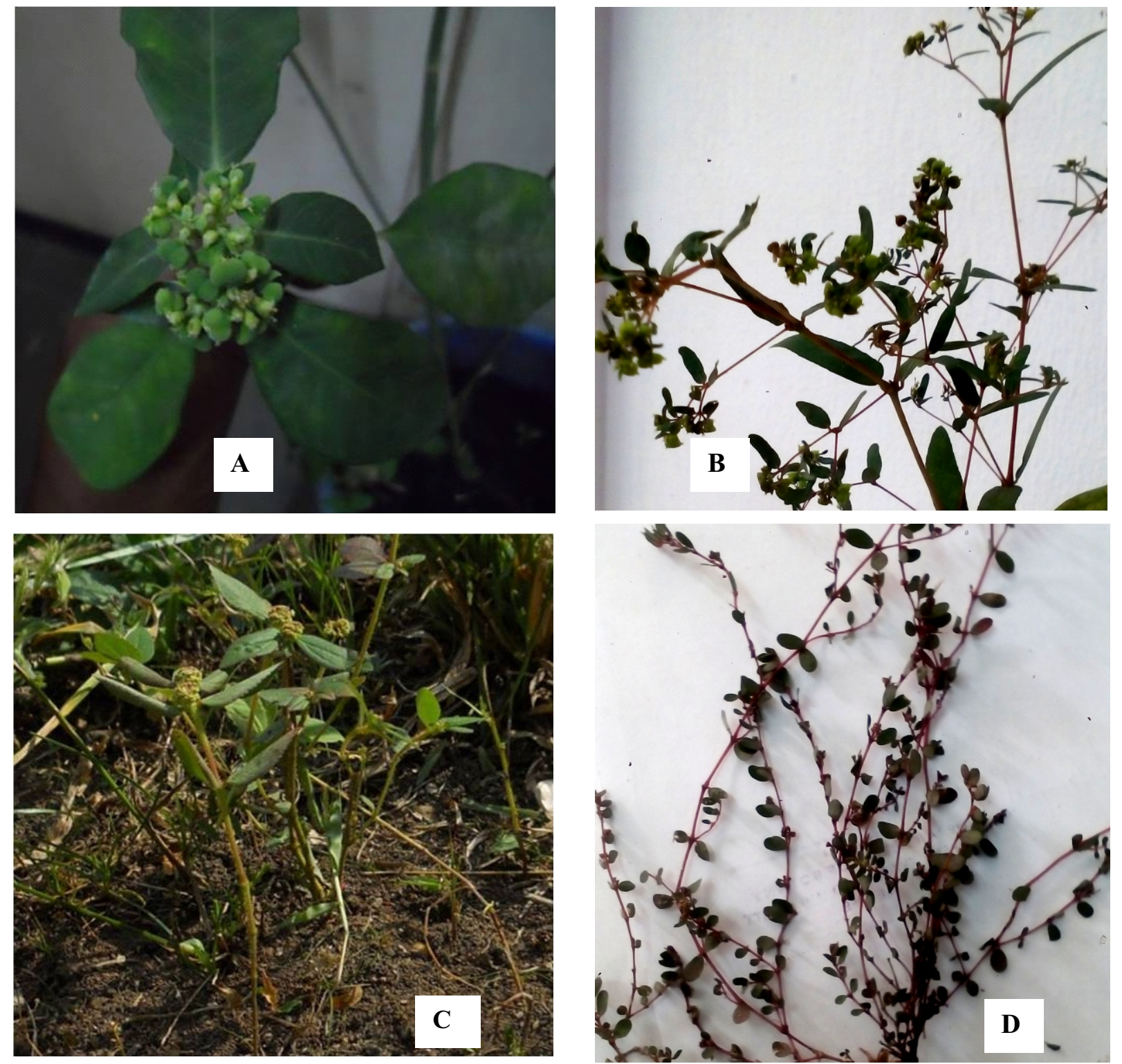

Figure 1: Habit of Euphorbia Species Studied A: Euphorbia heterophylla; B: Euphobia hyssopifolia; C: Euphorbia hirta; D: Euphorbia prostrata 
Table 1: Comparative Reproductive Biology of the Euphorbia Species Studied

\begin{tabular}{|c|c|c|c|c|}
\hline Character & $\begin{array}{l}\text { Euphorbia } \\
\text { beteropbylla }\end{array}$ & $\begin{array}{l}\text { Euphorbia } \\
\text { byssopifolia }\end{array}$ & Euphorbia birta & Euphorbia prostrata \\
\hline $\begin{array}{l}\text { Number of days to } \\
\text { seedling } \\
\text { emergence }\end{array}$ & 5 & 5 & 5 & 3 \\
\hline $\begin{array}{l}\text { Percentage } \\
\text { Germination }(\%)\end{array}$ & 11.6 & 42.5 & 12.5 & 17.5 \\
\hline $\begin{array}{l}\text { Number of days to } \\
50 \% \text { Flowering }\end{array}$ & 48 & 47 & 58 & 44 \\
\hline Inflorescence type & $\begin{array}{l}\text { Cyanthium (cyme), } \\
\text { bisexual; pedicel green; } \\
\text { perianth white and } \\
\text { glabrous }\end{array}$ & $\begin{array}{l}\text { Cyanthium (cyme), } \\
\text { bisexual; pedicel green; } \\
\text { perianth white and } \\
\text { glabrous }\end{array}$ & $\begin{array}{l}\text { cyanthium (cyme), } \\
\text { bisexual; pedicel green, } \\
\text { perianth green and } \\
\text { pubescent }\end{array}$ & $\begin{array}{l}\text { cyanthium (cyme), } \\
\text { bisexual; pedicel green; } \\
\text { perianth green and } \\
\text { pubescent }\end{array}$ \\
\hline Pistil & $\begin{array}{l}\text { Ovary superior, } \\
\text { glabrous, 3-lobed; } \\
\text { placentation axile; style } \\
\text { single, hollow; stigma } \\
\text { reddish brown, } \\
\text { branched into four }\end{array}$ & $\begin{array}{l}\text { Ovary superior, } \\
\text { glabrous, disc shaped, } \\
\text { green in colour; } \\
\text { placentation axile, style } \\
\text { single, hollow, green; } \\
\text { stigma branched into } \\
\text { four }\end{array}$ & $\begin{array}{l}\text { Ovary superior, } \\
\text { glabrous, cylindrical in } \\
\text { shape, green in colour; } \\
\text { placentation axile; style } \\
\text { single, hollow, green in } \\
\text { colour; stigma fused, } \\
\text { horse shoe shaped }\end{array}$ & $\begin{array}{l}\text { Ovary superior, highly } \\
\text { pubescent, 3-lobed, } \\
\text { green in colour; } \\
\text { placentation axile; style } \\
\text { single, hollow, green in } \\
\text { colour; stigma fused, } \\
\text { branched into four }\end{array}$ \\
\hline Stamen & $\begin{array}{l}\text { Hypogynous, } \\
\text { epipetalous; filament } \\
\text { green; anther sticky, } \\
\text { brown, numerous and } \\
\text { attached to the wall of } \\
\text { the perianth; average } \\
\text { pollen size } 3.5 \pm 0.04 \\
\mu \mathrm{m} ; \text { pollen viability } \\
83.49 \%\end{array}$ & $\begin{array}{l}\text { Hypogynous, } \\
\text { epipetalous; filament } \\
\text { green, anther sticky and } \\
\text { brown, numerous and } \\
\text { also attached to the } \\
\text { wall of the perianth; } \\
\text { average pollen size of } \\
1.535 \pm 0.07 \mu \mathrm{m} \text {; pollen } \\
\text { viability } 62.78 \%\end{array}$ & $\begin{array}{l}\text { Hypogynous, } \\
\text { epipetalous; filament } \\
\text { green, anther sticky, } \\
\text { brown, numerous and } \\
\text { attached to the wall of } \\
\text { the perianth; average } \\
\text { pollen size of } 1.225 \pm \\
0.02 \mu \mathrm{m} \text {; pollen viability } \\
62.14 \%\end{array}$ & $\begin{array}{l}\text { hypogynous, } \\
\text { epipetalous; filament } \\
\text { green, anther sticky, } \\
\text { brown, numerous and } \\
\text { attached to the wall of } \\
\text { the perianth; average } \\
\text { pollen size of } 1.225 \pm \\
0.02 \mu \mathrm{m} \text {; pollen viability } \\
96.04 \%\end{array}$ \\
\hline Period of anthesis & $9 \mathrm{am}-11 \mathrm{am}$ & $9 \mathrm{am}-11 \mathrm{am}$ & $9 \mathrm{am}-11 \mathrm{am}$ & $9 \mathrm{am}-11 \mathrm{am}$ \\
\hline Pollinators & $\begin{array}{l}\text { Calliphora vomitora } \\
\text { (Blue-fly) }\end{array}$ & $\begin{array}{l}\text { Calliphora vomitora } \\
\text { (Blue-fly). }\end{array}$ & $\begin{array}{l}\text { Anthrenus verbasci } \\
\text { (Carpet bettles) and } \\
\text { Chortoicetes } \\
\text { terminifera (locust) }\end{array}$ & $\begin{array}{l}\text { Anthrenus verbasci } \\
\text { (Carpet bettles) and } \\
\text { Calliphora vomitora } \\
\text { (Blue-fly). }\end{array}$ \\
\hline Fruits & $\begin{array}{l}\text { Schizocarpous, } 3 \text {-lobed, } \\
\text { unripe fruit colour light } \\
\text { green, ripe fruit colour } \\
\text { green; an average of } 28 \\
\pm 26.74 \text { per plant }\end{array}$ & $\begin{array}{l}\text { Scizocarpous, 3-lobed, } \\
\text { unripe fruit colour } \\
\text { green, ripe fruit colour } \\
\text { lemon green; an } \\
\text { average of } 56 \pm 7.69 \\
\text { per plant }\end{array}$ & $\begin{array}{l}\text { Schizocarpous, } 3 \text {-lobed, } \\
\text { unripe fruit colour light } \\
\text { green, ripe fruit colour } \\
\text { green; an average of } 20 \\
\pm 5.76 \text { per plant }\end{array}$ & $\begin{array}{l}\text { Schizocarpous, 3-lobed, } \\
\text { unripe fruit colour light } \\
\text { green, ripe fruit colour } \\
\text { brownish green; an } \\
\text { average of } 42 \pm 5.88 \\
\text { per plant }\end{array}$ \\
\hline Seeds & $\begin{array}{l}\text { Carunculate, unripe } \\
\text { seed colour white, ripe } \\
\text { seed colour brown; an } \\
\text { average of } 70 \pm 16.88 \\
\text { per plant }\end{array}$ & $\begin{array}{l}\text { Carunculate, unripe } \\
\text { seed colour white, ripe } \\
\text { seed colour dark } \\
\text { brown; an average of } \\
40 \pm 2.62 \text { per plant }\end{array}$ & $\begin{array}{l}\text { Carunculate, unripe } \\
\text { seed white, ripe seed } \\
\text { red; an average of } 36 \pm \\
3.67 \text { per plant }\end{array}$ & $\begin{array}{l}\text { Carunculate, unripe } \\
\text { seed white, ripe seed } \\
\text { orange; an average of } \\
27 \pm 2.90 \text { per plant }\end{array}$ \\
\hline $\begin{array}{l}\text { Mode of seed } \\
\text { dispersal }\end{array}$ & Explosive mechanism & Explosive mechanism. & Explosive mechanism. & Explosive mechanism. \\
\hline
\end{tabular}

The photograph of a typical Euphorbia byssopifolia studied is shown in figure 1B. The seedlings emerged 5 days after sowing and had $42.5 \%$ germination. The number of days to $50 \%$ flowering was 47 days and it continued to bloom throughout the year. The inflorescence was cyathium (cyme), flowers were bisexual with green pedicel, glabrous perianth, white in colour; ovary superior, glabrous, disc shaped, green in colour; placentation axile, style single, hollow, green; stigma branched (four); stamen hypogynous, epipetalous; filament green, anther sticky and brown, numerous and also attached to the wall of the perianth; fruit scizocarpous, 3-lobed, unripe fruit colour green, ripe fruit colour lemon green; seed carunculate, unripe seed colour white, ripe seed colour dark brown (Figure 2). Pollinator that visited the inflorescence was Calliphora vomitora (Blue-fly). The mode of seed dispersal was by explosive mechanism. Anthesis took place between 9 am-11 am. Euphorbia hyssopifolia had an average pollen size of $1.535 \pm 0.07 \mu \mathrm{m}, 62.78 \%$ 
pollen viability; while the mean number of fruit and seed per stand were $56 \pm 7.69$ and $40 \pm 2.62$ respectively (Table 1$)$.

The photograph of a typical Euphorbia hirta studied is shown in figure 1C. The seedlings emerged 5 days after sowing and had 12.5\% germination. The number of days to $50 \%$ flowering was 58 days and it continued to bloom throughout the year. The inflorescence was cyathium (cyme), flowers bisexual with green pedicel, pubescent perianth, green in colour; ovary superior, glabrous, cylindrical in shape, green in colour; placentation axile; style single, hollow, green in colour; stigma fused, horse shoe shaped; stamen hypogynous, epipetalous; filament green, anther sticky, brown, numerous and attached to the wall of the perianth; fruit schizocarpous, 3lobed, unripe fruit colour light green, ripe fruit colour green; seed carunculate, unripe seed white, ripe seed red (Figure 2). Pollinators that visited the inflorescence were Anthrenus verbasci (Carpet beetles) and Chortoicetes terminifera (locust) and the mode of seed dispersal was by explosive mechanism. Anthesis took place between 9 am $11 \mathrm{am}$ in the morning. Euphorbia hirta had an average pollen size of $1.225 \pm 0.02 \mu \mathrm{m}$ and $62.14 \%$ pollen viability; while the mean number of fruit and seed per stand were $20 \pm 5.76$ and 36 \pm 3.67 respectively (Table 1$)$.
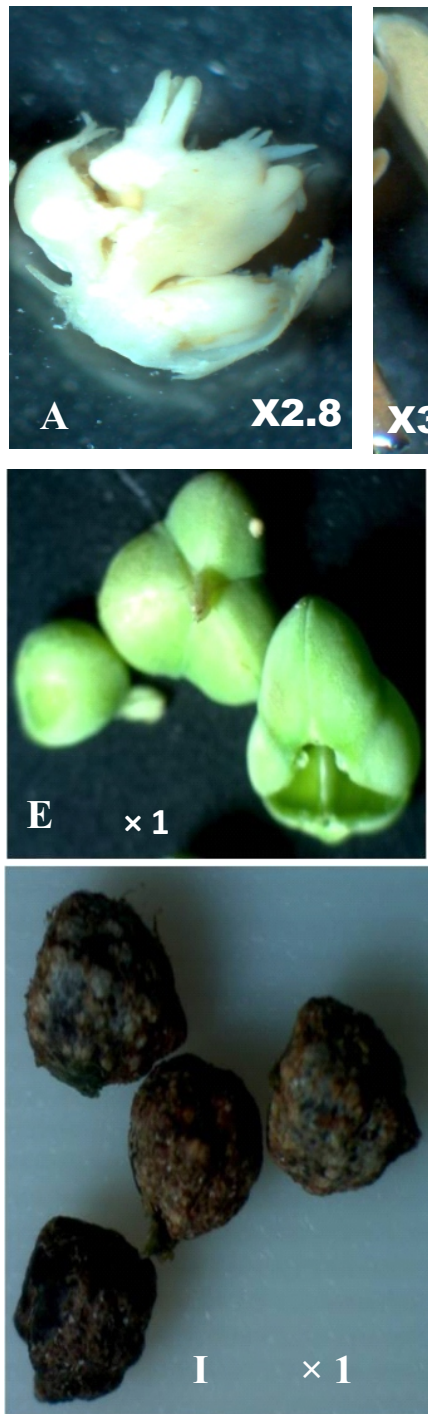
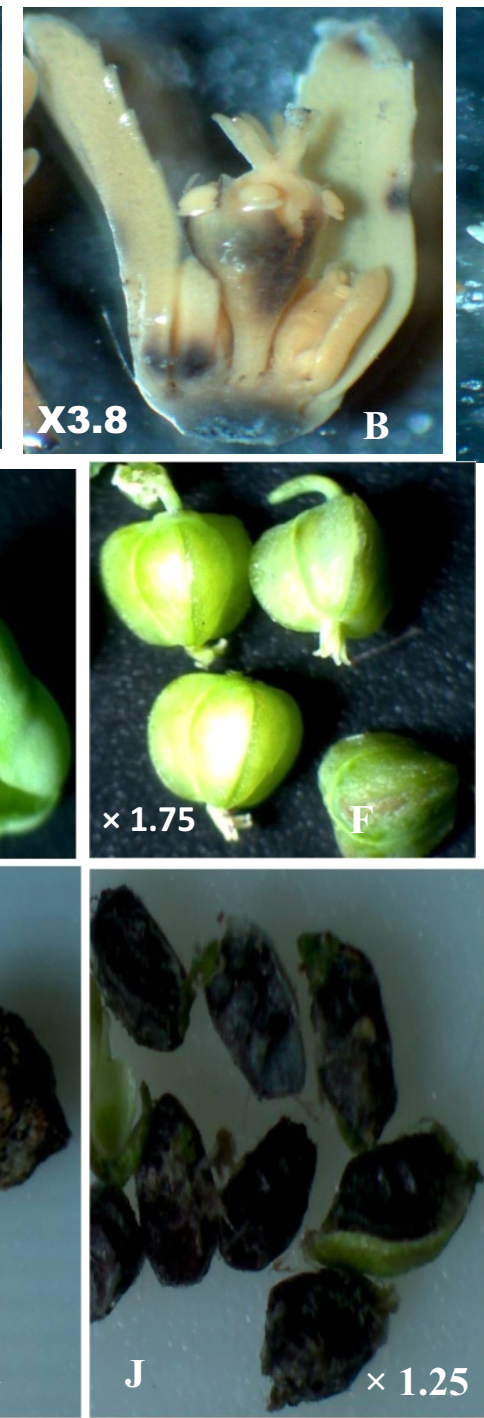
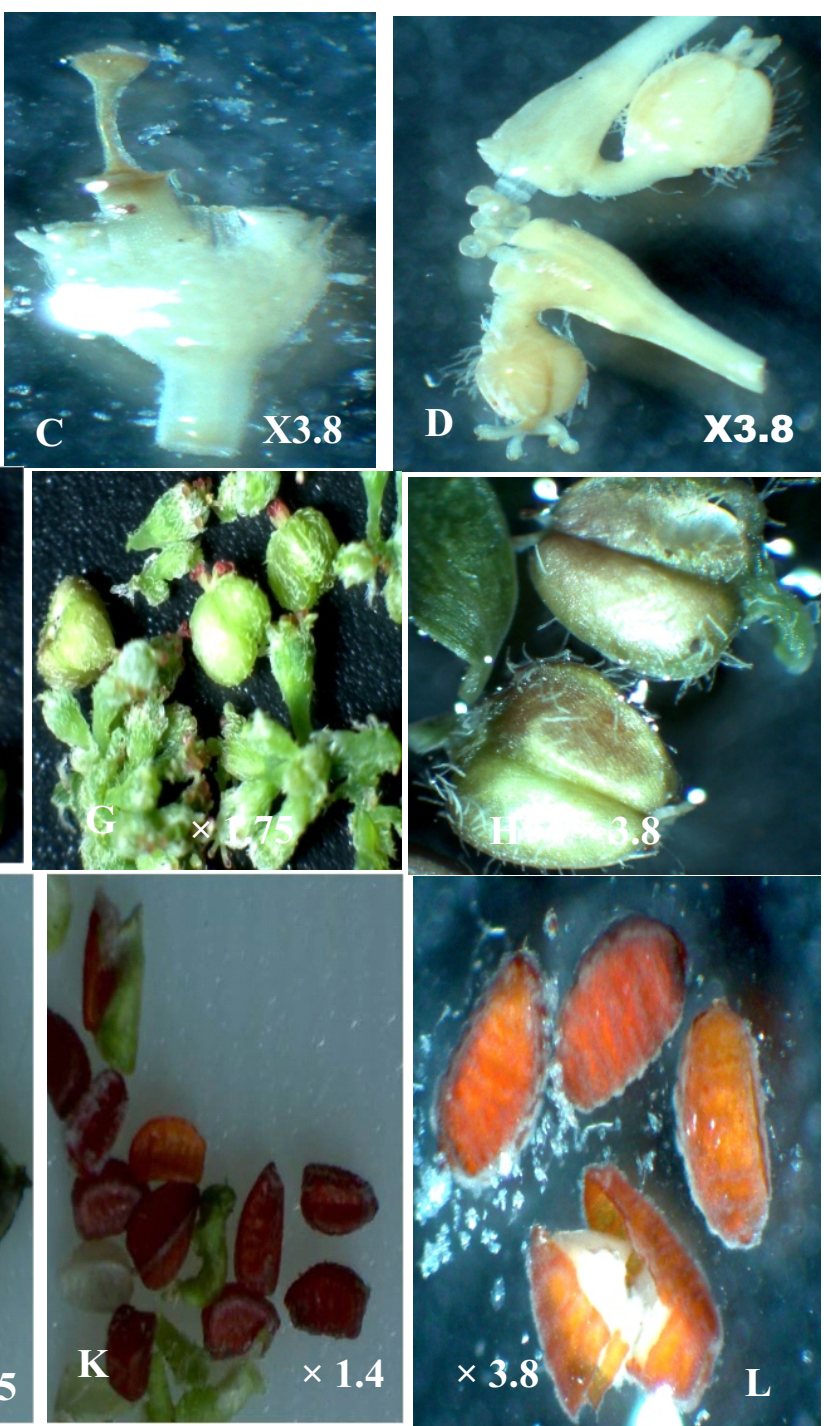

Figure 2: Cyathium, Fruits and Seeds of Euphorbia Species Studied

A: Cyathium of E. heterophylla; B: Cyathium of E. hyssopifolia; C: Cyathium of E. hirta; D: Cyathium of E. prostrata; E: Friuts of E. heterophylla; F: Friuts of E. hyssopifolia; G: Friuts of E. hirta; H: Friuts of E. prostrata; I: Seeds of $E$. heterophylla; J: Seeds of E. hyssopifolia; K: Seeds of E. hirta; L: Seeds of E. prostrata 
The photograph of a typical Euphorbia birta studied is shown in figure 1C. The seedlings emerged 5 days after sowing and had 12.5\% germination. The number of days to $50 \%$ flowering was 58 days and it continued to bloom throughout the year. The inflorescence was cyathium (cyme), flowers bisexual with green pedicel, pubescent perianth, green in colour; ovary superior, glabrous, cylindrical in shape, green in colour; placentation axile; style single, hollow, green in colour; stigma fused, horse shoe shaped; stamen hypogynous, epipetalous; filament green, anther sticky, brown, numerous and attached to the wall of the perianth; fruit schizocarpous, 3lobed, unripe fruit colour light green, ripe fruit colour green; seed carunculate, unripe seed white, ripe seed red (Figure 2). Pollinators that visited the inflorescence were Anthrenus verbasci (Carpet beetles) and Chortoicetes terminifera (locust) and the mode of seed dispersal was by explosive mechanism. Anthesis took place between 9 am $11 \mathrm{am}$ in the morning. Euphorbia hirta had an average pollen size of $1.225 \pm 0.02 \mu \mathrm{m}$ and $62.14 \%$ pollen viability; while the mean number of fruit and seed per stand were $20 \pm 5.76$ and 36 \pm 3.67 respectively (Table 1$)$.

The photograph of a typical Euphorbia prostrata studied is shown in figure 1D. The seedlings emerged 3 days after sowing and had 17.5\% germination. The number of days to $50 \%$ flowering was 44 days and it continued to bloom throughout the year. The inflorescence was cyathium (cyme), flowers bisexual with green pedicel, pubescent perianth, green in colour; ovary superior, highly pubescent, 3-lobed, green in colour; placentation axile; style single, hollow, green in colour; stigma fused, branched into four; stamen hypogynous, epipetalous; filament green, anther sticky, brown, numerous and attached to the wall of the perianth; fruit schizocarpous, 3lobed, unripe fruit colour light green, ripe fruit colour brownish green; seed carunculate, unripe seed white, ripe seed orange (Figure 2). Pollinators that visited the inflorescence were Antbrenus verbasci (Carpet beetles) and Calliphora vomitora (Blue-fly). The mode of seed dispersal was by explosive mechanism. Anthesis took place between 9 am - 11 am. Euphorbia prostrata had an average pollen size of $1.225 \pm 0.02 \mu \mathrm{m}$ and the percentage pollen viability was $96.04 \%$. The mean number of fruit and seed per stand were $42 \pm 5.88$ and $27 \pm 2.90$ respectively (Table 1 ).

In the four species studied, there was a very short interval of about 10 days between the flowering period and the fruiting period. Once fruiting commenced, the period of flowering and the period of fruiting overlapped such that the plants continued to produce flowers and fruits concurrently all through the remaining part of the year.

\section{DISCUSSION}

Understanding reproductive biology helps to clarify the potential use and value of characters in systematic treatments (Anderson et al., 2002). In this study, using floral features to characterize Euphorbia heterophylla, E. hyssopifolia, E. hirta and $E$. prostrata has actually helped in identifying marked differences that could be useful in delimiting the four species. According to Anderson et al. (2002) systematics and reproductive biology have been intertwined through botanical history because they both rely on reproductive characters.

The number of days from seedling emergence (35 days) to $50 \%$ flowering ( 44 - 58 days) was relatively short (Table 1) compared to the period of flowering, fruiting and seed dispersal (continuous throughout the remaining part of the year). This implies that the four species of Euphorbia studied exhibited r-strategy, expending more time and allocation of resources on their reproductive phases than their vegetative phases. According to Gadgil and Solbrig (1972) herbaceous plants tend to be r-strategists in comparison to trees.

The movement of anther to the stigma in the four Euphorbia species studied was enhanced by the presence of the brown liquid chemical substance on the cyathium as well as the different insects which were probably attracted to the various inflorescences of the species studied due to their floral attributes. According to Harder and Johnson (2009), floral traits like flower size, shape, colour, scents and nectar content can strongly influence pollinator visitation rates, number of 
pollen grain transferred between flowers and seed production.

It is also noteworthy that Calliphora vomitora (Blue-fly) was found visiting the inflorescence of both E. heteropbylla, E. byssopifolia and E. prostrata; while Anthrenus verbasci (Carpet beetles) visited both $E$. hirta and E. prostrata. Chortoicetes terminifera (locust) was found on only E. hirta. According to Ollerton (2017) the relationship between pollinators and plants range from generalist pollinators to highly specialized pollinators; and this relationship can vary depending on changing pollinator abundance during the year.

Pollen viability (Table 1) varied in the four Euphorbia species studied ranging from $62.14 \%$ in E. hirta to $96.04 \%$ in E. prostrata; and this did not correlate with the pollen sizes. E. heterophylla with pollen viability of $83.49 \%$ had pollen size of $3.5 \pm 0.04 \mu \mathrm{m} ;$ E. hyssopifolia with pollen viability of $62.78 \%$ had pollen size of $1.535 \pm 0.07 \mu \mathrm{m} ; E$. hirta with pollen viability of $62.14 \%$ had pollen size of $1.225 \pm 0.02 \mu \mathrm{m}$; while $E$. prostrata with pollen viability of $96.04 \%$ had pollen size of 1.225 $\pm 0.02 \mu \mathrm{m}$. This implies that the pollen sizes of these species did not reveal any significant effect on their viability. According to Oselebe et al. (2014) pollen viability determines the ability of pollen grains to effect fertilization, hence fruit set and differences in pollen viability among genotypes are largely of genetic origin.

The seeds of the four species of Euphorbia genus studied were dispersed by explosive mechanism due to the schizocarpic nature of the fruit which split open when ripen and dry to disperse the seeds. According to Hufhuis and Hay (2017) explosive seed dispersal is an example of autochory, where seeds are dispersed by a plant's own mechanisms and it provides a valuable opportunity for plants to move from place to place. This mechanism could be responsible for their spread in cultivated fields, gardens, roadsides and waste lands.

\section{CONCLUSION}

This study revealed significant floral traits such as differences in perianth texture, perianth colours, ripen fruit colours, ripen fruit texture, ripen seed colour, ripen seed texture and shape of style which could be valuable in delimiting the four Euphorbia species investigated. It also showed that the four species of Euphorbia studied exhibited r-strategy, expending more time and allocation of resources on their reproductive phases than their vegetative phases while dispersing their seeds through explosive mechanism; thus enhancing their spread and ability to invade cultivated fields, road sides and waste lands.

\section{REFRENCES}

Anderson, G.J., Johnson, S.D., Neal, P.R. and Bernardello, G. 2002. Reproductive biology and plant systematic: the growth of a symbiotic association. Taxon, 51: 637 $-653$.

Bolaji, A.O. and Nwokeocha, C.C. 2013. Issues concerning reproductive isolation in a rice hybrid swarm involving Oryza sativa Linn. O. longistaminata A. Chev. et Roehr. and Oryza glaberrima Steud. located in Jebba Nigeria. International Journal of Biological and Chemical Science, 7(5): 2040-2049.

Bolaji, A.O., Olojede, C.B, Famurewa, A.A. and Faluyi, J.O. 2015. Morphological and cytological studies of Euphorbia byssopifolia L. and Euphorbia beterophylla L. from Ile-Ife, Nigeria. Nigerian Journal of Genetics, 28: 15-18.

Bolaji, A.O., Adeniran, O.I., Awotunde, A. and Akinpelu, B.A. (2019). Evaluation of chemical composition, anti-inflammatory, antioxidant and cytotoxic potential of leaf and root extracts of Euphorbia graminae. Tropical Journal of Natural Product Research, 3(6): 201-209.

Falodun, A. and Agbakwuru, E. O. 2004. Phytochemical analysis and laxative activity of Euphorbia heterophylla Linn (Euphorbiaceae). Pakistan of Journal Science Research, 47(5):345-348

Faluyi, J.O. 1985. Cytogenetic study in the Genus Oryza Linn. I. Investigation of two interspecific hybrids and intervarietal cross. Nigerian Journal of Genetics, 6: 116. 
Gadgil, M. and Solbrig, O.T. 1972. The concept of r- and K- selection: Evidence from wild flowers and some theoretical consideration. The American Naturalist, 106: $14-31$.

Harder, L.D. and Johnson, S.D. 2009. Darwin's beautiful contrivances: evolutionary and functional evidence. New Phytologist, 183: 530-545.

Herbenger, J. 1997. World Weeds. In: Natural Histories and Distribution. John Wiley and Sons (editors). New York, USA. Pp. 249-265.

Huang, L., Chen, S. and Yang, M. 2012. Euphorbia hirta: A review on its ethnopharmacology, phytochemistry and pharmacology. Journal of Medicinal Plant Research, 6(39): 5176-5186.

Hufhuis, H. and Hay, A. 2017. Explosive seed dispersal. New Phytologist, 216: 339 342.

Hutchinson, J. and Dalziel, J.M. 1954. Floral of West Tropical Africa. 2nd Edition, Crown Agents of Oversea Governments and Administrations. Mill Bank, London S.W.I. 1(1): 417-422.

Johnson, P., Abdurahman, E., Tiam, E., Abdo-
Aguye, I. and Hussaini, I. 1999. Euphorbia birta leaf extracts increase urine output and electrolytes in rats. Journal of Ethnopharmacology, 65(1): 63-72.

Ollerton, J. 2017. Pollinator diversity: distribution, ecological function and conservation. Annual Review of Ecology, Evolution and Systematics, 48: 353-376.

Oselebe, H.O., Nnamani, C.V. and Ikeh, E. 2014. Pollen diversity, viability and floral structure of some Musa genotypes. Nigerian Journal of Biotechnology, 27: 21 -27 .

Prenner, G. and Rudall, P. 2007. Comparative ontogeny of the cyanthium in Euphorbia (Euphorbiaceae) and its allies: exploring the organ-flower-inflorescence boundary. American Journal of Botany, 94(10): 1612-1629.

Sandeep, B.P., Nilofar, S.N. and Chandrakant, S.M. 2009. Review on phytochemistry and pharmacological aspect of Euphorbia birta Linn. Journal of Pharmaceutical Research and Health Care, 1:113-133.

Tabuti, J.R.S. 2008. Euphorbia hirta L. Journal of Ethnopharmacology, 122(2):273-293. 